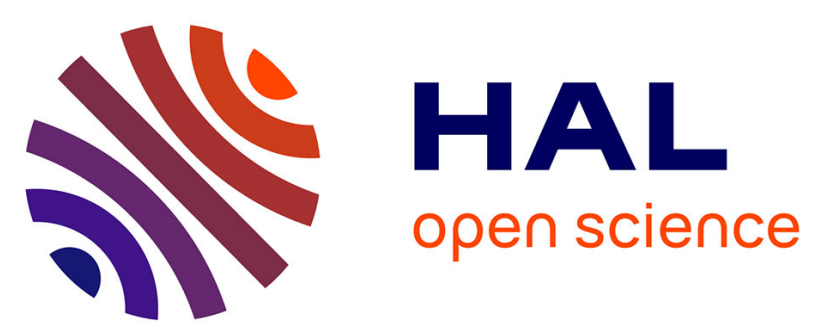

\title{
Enediynes Bearing Polyfluoroaryl Sulfoxide as New Antiproliferative Agents with Dual Targeting of Microtubules and DNA
}

Cyril Borie, Shovan Mondal, Tanzeel Arif, Manon Briand, Hugo Lingua, Frederic Dumur, Didier Gigmes, Pierre Stocker, Bernadette Barbarat, Viviane Robert, et al.

\section{To cite this version:}

Cyril Borie, Shovan Mondal, Tanzeel Arif, Manon Briand, Hugo Lingua, et al.. Enediynes Bearing Polyfluoroaryl Sulfoxide as New Antiproliferative Agents with Dual Targeting of Microtubules and DNA. European Journal of Medicinal Chemistry, 2018, 148, pp.306-313. 10.1016/j.ejmech.2018.02.030 . hal-01765802

\section{HAL Id: hal-01765802 https://hal.science/hal-01765802}

Submitted on 13 Apr 2018

HAL is a multi-disciplinary open access archive for the deposit and dissemination of scientific research documents, whether they are published or not. The documents may come from teaching and research institutions in France or abroad, or from public or private research centers.
L'archive ouverte pluridisciplinaire HAL, est destinée au dépôt et à la diffusion de documents scientifiques de niveau recherche, publiés ou non, émanant des établissements d'enseignement et de recherche français ou étrangers, des laboratoires publics ou privés. 


\section{Enediynes Bearing Polyfluoroaryl Sulfoxide as New Antiproliferative Agents with Dual Targeting of Microtubules and DNA.}

Cyril Borie, ${ }^{\mathrm{a}}$ Shovan Mondal, ${ }^{\mathrm{a}, \mathrm{b}}$ Tanzeel Arif, ${ }^{\mathrm{a}}$ Manon Briand, ${ }^{\mathrm{a}}$ Hugo Lingua, ${ }^{\text {a }}$ Frédéric Dumur, ${ }^{\mathrm{a}}$ Didier Gigmes, ${ }^{\mathrm{a}}$ Pierre Stocker, ${ }^{\mathrm{a}}$ Bernadette Barbarat, ${ }^{\mathrm{c}, \mathrm{d}}$ Viviane Robert, ${ }^{\mathrm{e}}$ Cendrine Nicoletti, ${ }^{\text {e }}$ Daniel Olive, ${ }^{\text {c,d }}$ Marc Maresca, ${ }^{e^{*}}$ Malek Nechab ${ }^{a^{*}}$

${ }^{\text {a }}$ Aix Marseille Univ, CNRS, Institut de Chimie Radicalaire UMR 7273, F-13390 Marseille, France

${ }^{\mathrm{b}}$ Department of Chemistry, Syamsundar College, Shyamsundar 713424, West Bengal, India

${ }^{c}$ Centre de Recherche en Cancérologie de Marseille (CRCM) UMR-INSERM1068-IBiSA Cancer Immunomonitoring Platform, Inserm, U1068, France

d Institut Paoli Calmettes, 27, boulevard Lei Roure, BP30059, 13273, Marseille Cedex 09, France

e Aix Marseille Univ, CNRS, Centrale Marseille, iSm2 UMR 7313, F-13397, Marseille, France corresponding authors: m.maresca@univ-amu.fr; malek.nechab@univ-amu.fr

Abstract: A novel series of enediynes possessing pentafluorophenylsulfoxide have been developed. The innovative compounds possess antiproliferative activity against a broad panel of human cancer cells originating from breast, blood, lung, kidney, colon, prostate, pancreas or skin with $\mathrm{IC}_{50}$ ranging from 0.6 to $3.4 \mu \mathrm{M}$. The antiproliferative activity of enediynes in darkness is associated to their ability to compromise microtubule network. In addition, exposure to UV leads to double-stranded DNA cleavage caused by the newly synthesized molecules reducing further their $\mathrm{IC}_{50}$ in nanomolar range against human tumor cells, including chemoresistant pancreatic cancer cells. Taken together, the examined data demonstrate that enediynes possessing pentafluorosulfoxide are promising molecules in the cancer therapy.

Keywords: Enediynes, Anticancer, Microtubules, DNA cleavage, light activation.

\section{1- Introduction}

In the last decades, the enediynes derived from natural products, such as calicheamicins, and their synthetic analogues have been used in DNA cleavage studies [1]. These molecules were found as promising therapeutic agents against many types of cancers [2]. Their biological activity stems from cyclization of the enediyne moiety to a highly reactive 1,4-benzenoid diradical $[1,3]$. The latter is able to abstract hydrogen atoms from the sugar phosphate backbone of adjacent strands of DNA causing scission of the DNA double helix. Despite the great number of enediynes reported to display anti-tumor activities, there is a need of development of new compounds as potential drugs against chemoresistant cancers like pancreatic tumors. To address this issue, design of novel molecules presenting a dual activity is a challenging task [4]. 
During our recent interest in cascade reactions involving enediynes [5], we observed a high reactivity of pentafluorophenylsulfone when compared to their non-fluorinated analogues. Non-fluorinated compound 5 (Figure 1) has been reported to exhibit a moderate activity (IC50 $\sim 20 \mu \mathrm{M}$ ) against various tumor cells [6], Because, organic molecules containing fluorine atoms are recognized to provide a high impact in medicinal chemistry [7], we report herein the synthesis of a novel series of enediynes containing polyfluorinatedsulfoxides and their actions against tumor cells related to their dual activity targeting microtubules and DNA photocleavage.

\section{Results and discussion}

\section{Synthesis}

The syntheses of compounds have been realized in 5 steps (Scheme 1). The first step consists of a Sonogashira coupling of protected propargyl alcohol and 1,2-diiodobenzene derivatives using $\mathrm{Pd}\left(\mathrm{PPh}_{3}\right)_{4}$ [8]. A second Sonogashira cross coupling afforded the enediynes moiety 2 . The free alcohol was then mesylated and immediately displaced, without any purification, by pentafluorothiophenol to afford the corresponding thioether 3. The $m$-CPBA oxidation followed by a deprotection with pyridinium $p$-toluenesulfonate (PPTS) afforded the desired products $\mathbf{4 a -}$ $\mathbf{4 k}$ with satisfactory overall yields (Figure 1).

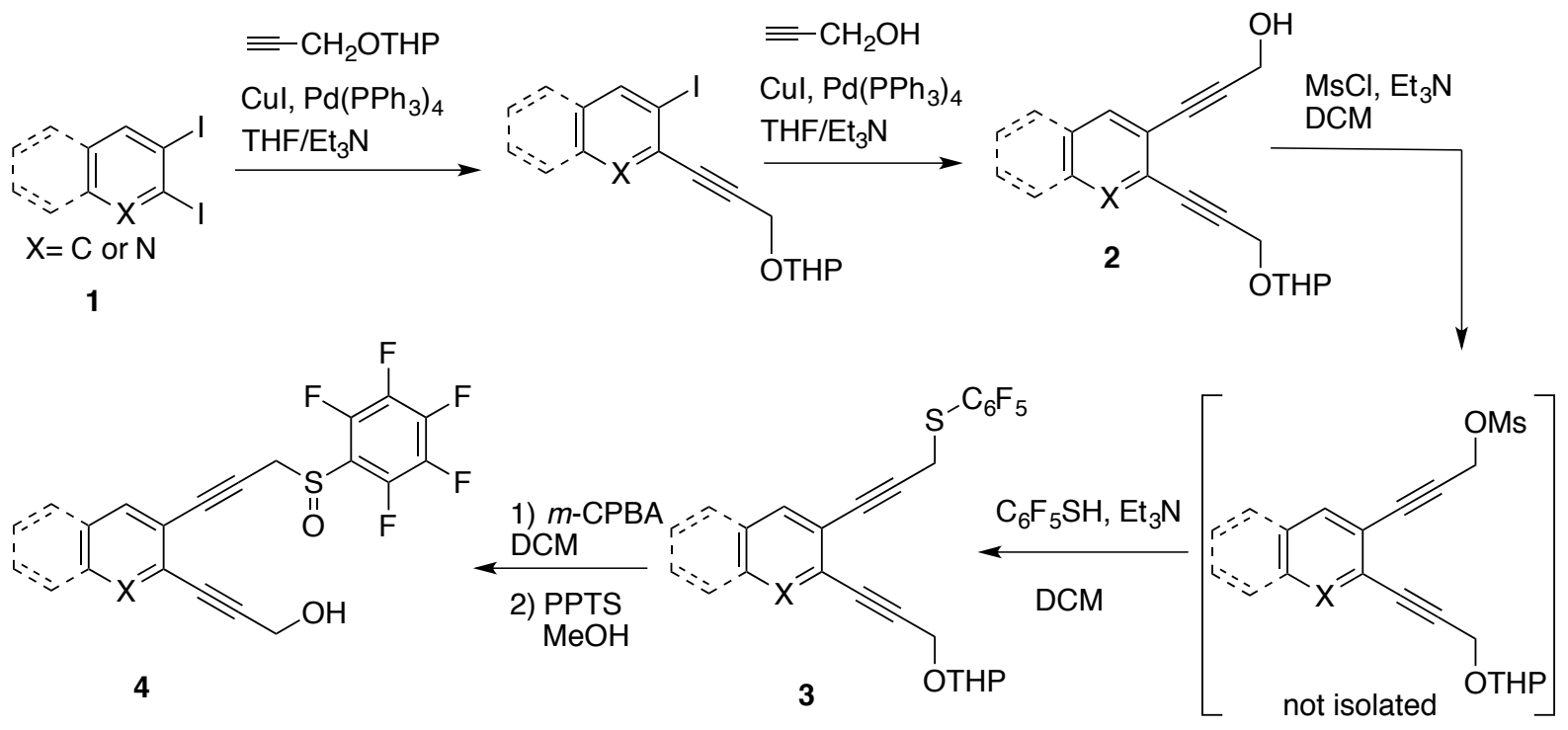

Scheme 1 Synthetic route for enediynes 4

\section{In-vitro antiproliferative activities}

Propargyl sulfones constitute a class of bioactive compounds acting on DNA and cell division [9]. To this end, we evaluated the capacity of compounds 4-7 to inhibit the proliferation of cancer cells measured by the Alamar Blue assays. The in-vitro antiproliferative effect, expressed as $\mathrm{IC}_{50}(50 \%$ inhibition of the cell proliferation), was first investigated using the human pancreatic tumor cells MIAPaCa-2. These cells were chosen since pancreatic cancer is a highly aggressive malignant disease with high chemoresistance and thus considerable efforts have to be furnished to solve this problem [10].

We have shown that the structural modification of the enediyne compounds has an influence on the activity against tumor cells. We first demonstrated that the presence of fluorine atoms (4a) has a crucial importance as it affords higher efficacy ( $\mathrm{IC}_{50}$ of $2.5 \mu \mathrm{M}$, corresponding to a 
4-fold increase compared to 5). The oxidation state of sulfur has also shown its importance, the sulfoxide $4 \mathbf{a}$ provided a better $\mathrm{IC}_{50}$ when it is compared to the sulfone analogue $4 \mathbf{b}$ ( IC $_{50}$ of 3.9 $\mu \mathrm{M})$. The elongation of side chain in $\mathbf{4} \mathbf{c}$ has however exhibited a detrimental effect $\left(\mathrm{IC}_{50}\right.$ of $>10$ $\mu \mathrm{M})$. The same observation has been made with naphthyl analogue $4 \mathbf{d}\left(\mathrm{IC}_{50}\right.$ of $\left.4.7 \mu \mathrm{M}\right)$. The presence of free alcohol seems to be not imperative for the activity, the azide $\mathbf{4 g}$ revealed the same $\mathrm{IC}_{50}$ as $4 \mathbf{a}$ ( $\mathrm{IC}_{50}$ of 2.4 and $2.5 \mu \mathrm{M}$, respectively). However, the presence of the two alkynes has been demonstrated to be important for the activity $\left(\mathrm{IC}_{50}\right.$ of $7.8 \mu \mathrm{M}$ for compound 4e). On the other hand, the presence of ethyl ester group on the aromatic ring (4f) allows a similar increase in the activity $\left(\mathrm{IC}_{50}\right.$ of $\left.1.6 \mu \mathrm{M}\right)$. The thiophene derivative 6 afforded an $\mathrm{IC}_{50}$ of $2.2 \mu \mathrm{M}$. Finally, the passage to pyridinyl compound $4 \mathbf{i}$ affords the best value of $\operatorname{IC}_{50}(0.8 \mu \mathrm{M})$. Again, the synthesis intermediates $\mathbf{4 h}$ and $\mathbf{4 j}$ confirmed that the presence of hydroxyl group is not essential. Based on these results, we then selected the heterocyclic enediyne $4 \mathbf{i}$ to continue our studies. It is interesting to recall that clinically used antitumor drug 5-fluoracil presents an $\mathrm{IC}_{50} 6$-fold higher than $\mathbf{4 i}[9 \mathrm{~b}, 11]$, and that gemcitabine, a widely used difluoro-drug in the treatment of pancreatic cancers, presented $\mathrm{IC}_{50}$ in the range of the selected compound $[12,13]$.
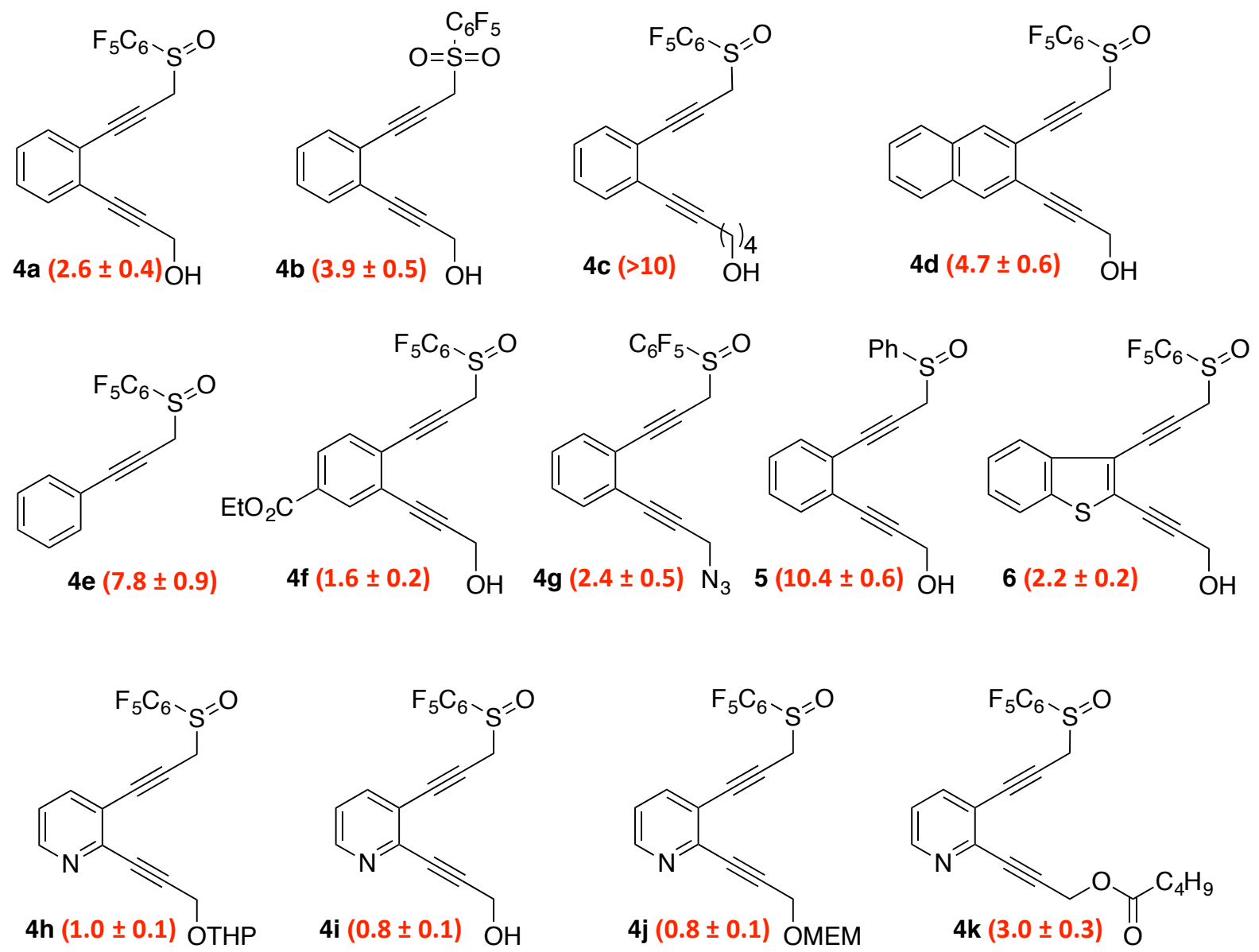

Figure 1 Enediynes Structure and their $\mathrm{IC}_{50}$ (in brackets)

Encouraged by these results obtained with pancreatic cancer cells, we screened a broad panel of human cancer cells originating from breast, blood, lung, kidney, colon, prostate or skin (Table 1). Results showed that compound $\mathbf{4 i}$ is active against all cancer cell types tested, exhibiting promising $\mathrm{IC}_{50}$ ranging from 0.6 to $3.4 \mu \mathrm{M}$, with $\mathrm{K} 562$ and MOLT-4 cells (blood 
cancer) showing the highest efficacy whereas the renal cell line A498 revealed the lowest sensitivity. This result suggests that this class of compounds can be used potentially to treat various forms and types of cancers.

Table 1: $\mathrm{IC}_{50}$ values of $\mathbf{4 i}$ in different cells

$\begin{array}{ll}\text { Cell lines } & \mathrm{IC}_{50}(\mu \mathrm{M}) \\ \text { MIAPaCa-2 (pancreas) } & 0.8 \pm 0.1 \\ \text { MDA-MB 231 (breast) } & 1.2 \pm 0.1 \\ \text { K562 (blood) } & 0.7 \pm 0.08 \\ \text { MOLT-4 (blood) } & 0.6 \pm 0.06 \\ \text { A549 (lung) } & 1.6 \pm 0.18 \\ \text { A498 (kidney) } & 3.4 \pm 0.2 \\ \text { CaCo-2 (colon) } & 1.0 \pm 0.12 \\ \text { PC-3 (prostate) } & 1.4 \pm 0.1 \\ \text { A431 (melanoma) } & 1.5 \pm 0.1 \\ \text { GERL 3.0 (melanoma) } & 0.9 \pm 0.1\end{array}$

\section{Mechanism of action.}

Based on their chemical structure, the mechanism by which compound $\mathbf{4}$ is giving biological activity was first hypothesized to be related to DNA break. As already mentioned in the introduction, biradicals issued from Bergman cyloaromatization (or Saito Myers cyclization) are able to abstract hydrogen atom from DNA backbone [1b]. Moreover, propargyl sulfones (or their allenic analogs) were already reported to act as alkylating agent [9b,14]. In order to confirm such activity, we investigated the ability of Enediynes 4a and 4i to cleave DNA using supercoiled plasmid pCDNA3 at $100 \mu \mathrm{M}$ concentration of the compounds. Surprisingly, intact DNA was recovered demonstrating that no cleavage is caused by these compounds.

Since DNA break was not involved in the anti-proliferative action of our compounds and questioned by the result seen with compound devoid of enediyne moiety $4 \mathbf{e}$ (Figure 1), we therefore turned our reflection to an alternative hypothesis. Indeed, a known anti-proliferative compound called T138067 sharing with our compounds the perfluorinated moiety (Figure 2) $[15,16]$. T138067 has been shown to act via a nucleophilic substitution in para position of its perfluorinated moiety allowing the binding of the molecule to a cysteine residue (Cys239) of tubulin resulting in microtubules depolymerisation and inhibition of the cell proliferation [15c]. We thus investigated if compounds 4 containing also the perfluorinated moiety possess antimicrotubules activity.

Indeed, pyridinyl compound $\mathbf{4 i}$ bears a parafluorobenzene sulfoxide, a molecular function that could act as a binding site through the nucleophilic attack of a thiol. Action against microtubules was thus investigated. A498 cells were treated with 4i, T138067 or with colchicine (two molecules known to affect microtubules network) for 1, 3, 6 and $12 \mathrm{~h}$ before labelling of microtubules with antibodies directed against $\beta$-tubulin (Figure 2). Results showed that although the action of compound $\mathbf{4 i}$ is slower than T138067 or colchicine, it results in a clear impact on microtubules integrity. 


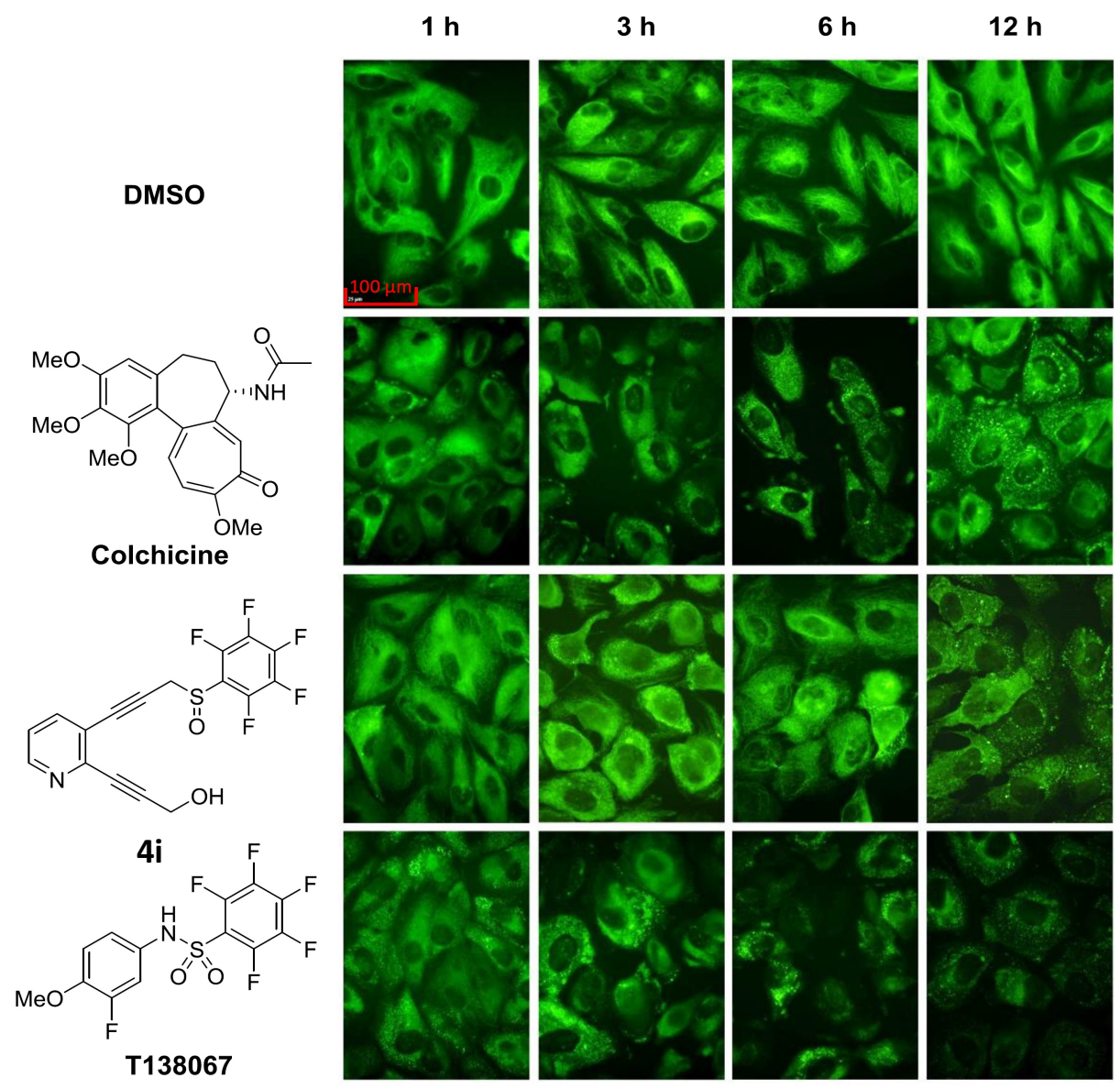

Figure 2: Time-dependent effect of compound $4 \mathrm{i}$ on microtubule network in $\mathrm{A498}$ cells. A498 cells were exposed for $1,3,6$ or $12 \mathrm{~h}$ to compound $4 \mathrm{i}$ at 5 time its $\mathrm{IC}_{50}$ value determined in proliferation assay. Cells were fixed and microtubule network (in green) was immunolabelled with antibody directed against beta tubulin.

Similarly, 4i treatment leads to alteration of the microtubules network in A549 and MIAPaCa-2 cells (Figure 3 ). The same result was obtained with other compounds of this family, with the exception of the non perfluorinated compound 5 (Figure 4). This compound bore a fully hydrogenated moiety and consequently showed no action on microtubules integrity. This result supports the hypothesis of the involvement of the fluorinated part of this family in an antimicrotubule activity, probably at the origin of their antiproliferative action on cancer cells. 


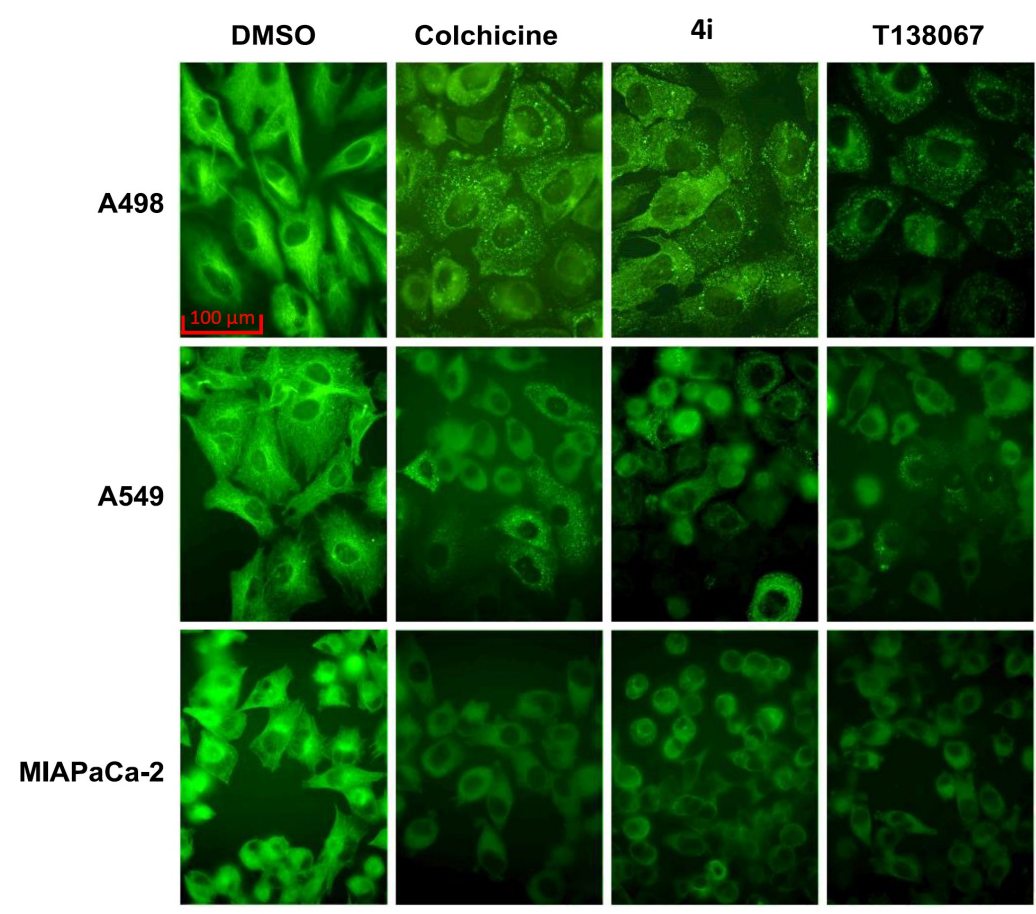

Figure 3: Effect of compound 4i on microtubule network of different cancer cells. A498, A549 and MIAPaCa-2 cells were exposed for $12 \mathrm{~h}$ to compound $4 \mathrm{i}$ at 5 time its $\mathrm{IC}_{50}$ value on each cell type determined in proliferation assay. After $12 \mathrm{~h}$, cells were fixed and microtubule network (in green) was immunolabelled with antibody directed against beta tubulin.

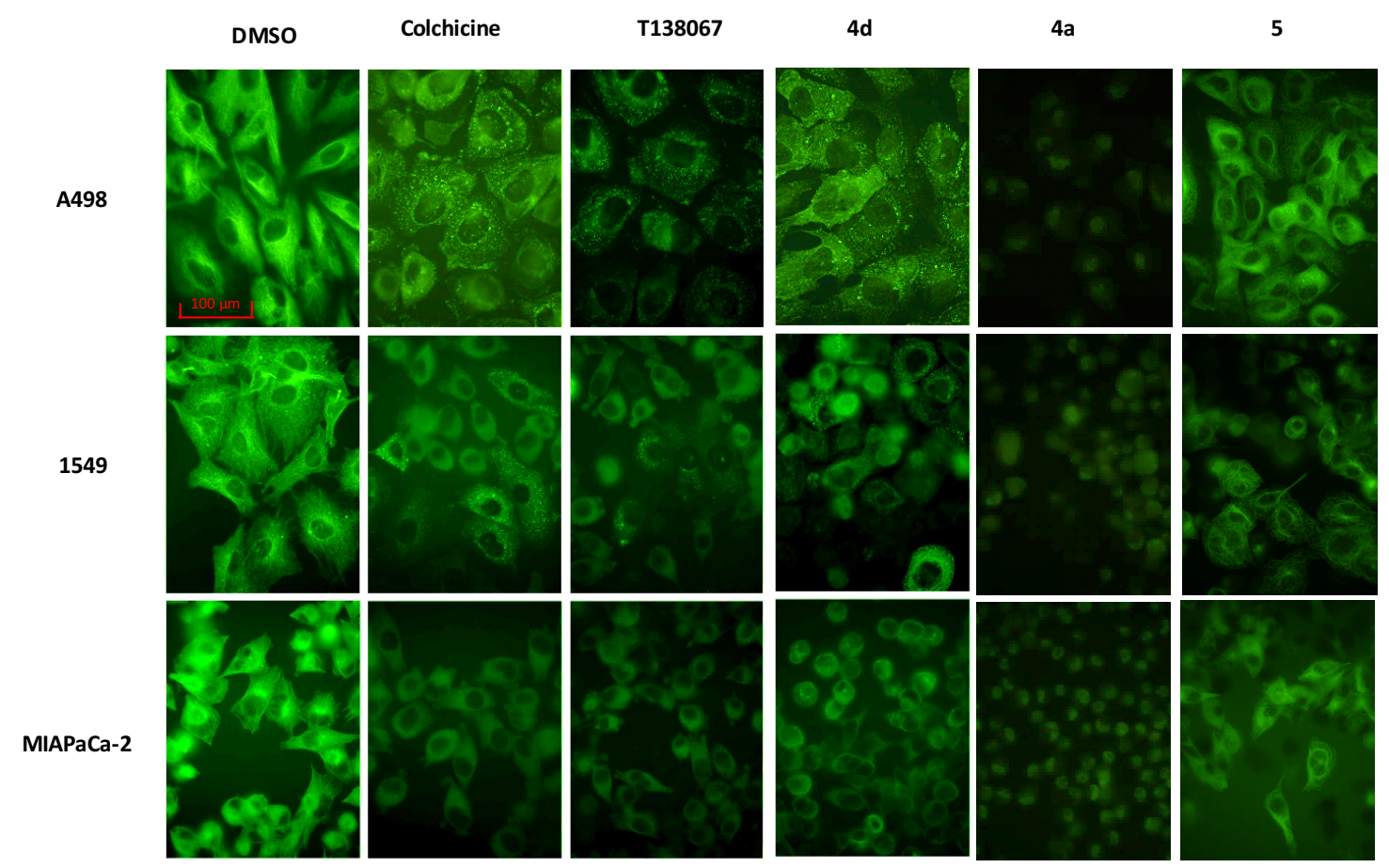

Figure 4: Effect of compounds 4d, 4a and 5 on microtubule network of different cancer cells. A498, A549 and MIAPaCa-2 cells were exposed for $12 \mathrm{~h}$ to compounds Colchincine, T138067 4d, 4a and 5, respectively at 5 time their IC50 value determined in proliferation assay. After $12 \mathrm{~h}$, cells were fixed and microtubule network (in green) was immunolabelled with antibody directed against beta tubulin. 


\section{Photocleavage:}

Since drug resistance is the major cause of failure of chemotherapeutics for further development, we thought that a drug possessing a dual activity will be more promising. Settling of the sulfoxide moiety was judiciously planned to this issue. Indeed, sulfoxide is known to be photochemically sensible [17] and more interestingly, it has been demonstrated that this entity is able to trigger DNA photocleavage [18]. The above enediynes were naturally investigated regarding their ability for DNA cleavage, upon excitation by light, using a plasmid relaxation assays [19]. So, although our compounds do not cause DNA break in the dark (Figure 5), we investigated if excitation by light leads to DNA cleavage [20]. The control experiments in the dark confirm the results of Figure 5 that the compounds are not able to cleave DNA. On another hand, when the compounds were irradiated, a full DNA cleavages were observed and more importantly, a double-stranded cleavage (form III) was detected on gel. This break is known to be more difficult to repair by enzymes and thus provides a better chance to initiate a cell death [21].

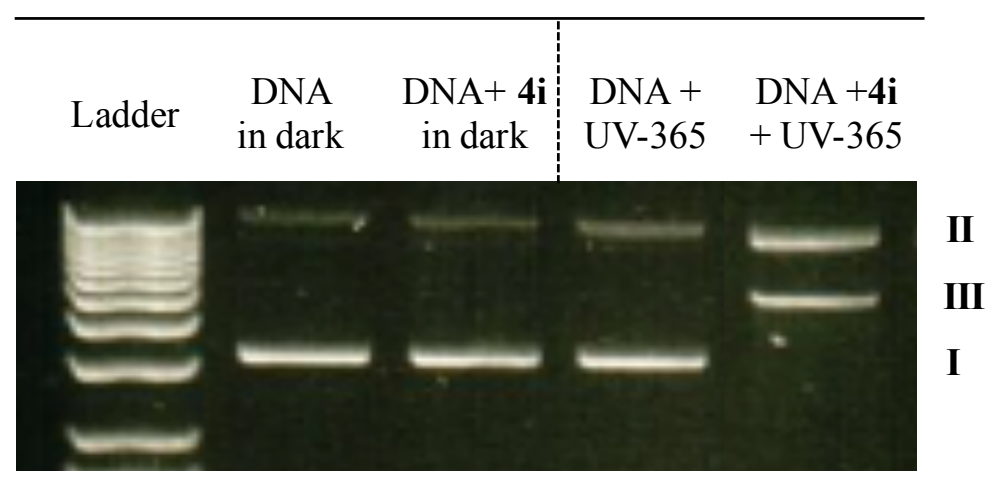

Figure 5. Photochemical cleavage ( $\lambda=365 \mathrm{~nm}$ during $1 \mathrm{~h})$ of pCDNA3 supercoiled DNA (20 $\mu \mathrm{M} / \mathrm{bp})$ by $4 \mathbf{i}(100 \mu \mathrm{M})$ in TE buffer.

Table 2: Antiproliferative activity of Enediyne 4i in the absence or presence of light

$\begin{array}{llll}\text { Cell-line } & \mathrm{IC}_{50} \text { in dark } & \mathrm{IC}_{50} \text { with light } & \text { Selectivity factor } \\ \text { MIAPaCa-2 } & 0.8 \pm 0.1 & 0.2 \pm 0.05 & 3.7 \\ \text { MDA-MB 231 } & 1.2 \pm 0.1 & 0.5 \pm 0.1 & 2.2 \\ \text { MOLT-4 } & 0.6 \pm 0.06 & 0.4 \pm 0.05 & 1.6 \\ \mathrm{~A} 549 & 1.6 \pm 0.18 & 0.8 \pm 0.1 & 2 \\ \mathrm{~A} 498 & 3.4 \pm 0.2 & 3.2 \pm 0.3 & 1.1 \\ \mathrm{CaCo}-2 & 1.0 \pm 0.12 & 0.5 \pm 0.17 & 2 \\ \text { PC-3 } & 1.4 \pm 0.1 & 0.5 \pm 0.14 & 2.5 \\ \text { A431 } & 1.5 \pm 0.1 & 1.1 \pm 0.07 & 1.3 \\ \text { GERL 3.0 } & 0.9 \pm 0.1 & 0.6 \pm 0.07 & 1.4\end{array}$

We then investigated if photo-activation of compound $4 \mathbf{i}$ increases its anti-proliferative effect on cancer cells. The Alamar Blue assay was used in the same conditions as above to determine the relative viability upon irradiation at $365 \mathrm{~nm}$ during 10 minutes with low energy of $0.6 \mathrm{~J} / \mathrm{cm}^{2}$. The results are summarized in Table 2. By comparing the dark and light-exposed conditions, we calculated an enhancement factor as the selectivity ratio of activity of compound $4 \mathbf{i}$ in the presence and absence of light. Results showed an increased efficiency in the presence of light 
in all of cell lines tested, particularly in the case of MIAPaCa-2, with a factor of 3.7 being reached with an anti-proliferative activity of $0.23 \mu \mathrm{M}$ after light exposure.

We then screened the pyridinyl derivatives $\mathbf{4 h}, \mathbf{4} \mathbf{j}$ and $\mathbf{4 k}$ regarding their ability to phototrigger cytotoxicity against MIAPaCa-2. Interestingly, the ester $\mathbf{4 k}$ has shown the best selectivity of factor 6 ( $\mathrm{IC}_{50}$ of $3 \mu \mathrm{M}$ in the dark and $0.5 \mu \mathrm{M}$ in the presence of light).

\section{Conclusion}

In this study, we have synthesized a dozen of enediynes that have been evaluated against pancreatic tumor cells (MIAPaca-2). The pyridinyl enediyne 4i revealed the highest antiproliferative activity $\left(\mathrm{IC}_{50}\right.$ of $\left.0.8 \mu \mathrm{M}\right)$. This compound was also active against a broad panel of human cancer cells like breast, blood, lung, kidney, colon, prostate and skin. Mechanistic study showed that $\mathbf{4 i}$ affects microtubules network which was unprecedented for such family of compound. Additionally, thanks to the presence of the sulfoxide moiety, we have succeeded in a photoactivation processe which increases the antiproliferative activity up to 3.71 times (IC50 reduced from 0.861 to $0.232 \mu \mathrm{M}$ ). DNA plasmid assays, confirmed the ability of this enediyne to trigger a double-strand cleavage.

\section{Experimental Section}

\section{Chemical synthesis of enediynes}

All reactions were carried out in dry glassware using magnetic stirring and a positive pressure of argon. Solvents are commercially available, most of them were used as purchased (analytical grade), without further purification. DCM was collected from a solvent purication system. THF and $\mathrm{Et}_{2} \mathrm{O}$ were distilled over sodium benzophenone ketyl prior to use. Dry state adsorption conditions and purification were performed on silica gel $60 \AA$ (70-230 mesh). Analytical thin layer chromatography was performed on pre-coated silica gel plates. Visualization was accomplished by UV $(254 \mathrm{~nm})$ and with phosphomolybdic acid in ethanol. 1H NMR spectra were recorded on $400 \mathrm{MHz}$ and $13 \mathrm{C}$ spectra were recorded at $100 \mathrm{MHz}$ or $75 \mathrm{MHz}$. Chemical shifts $(\delta)$ are reported in ppm. Signals due to residual protonated solvent (1H NMR) or to the solvent (13C NMR) served as the internal standard: $\mathrm{CDCl} 3$ (7.26 ppm and $77.16 \mathrm{ppm})$. Multiplicity is indicated by one or more of the following: s (singlet), $d$ (doublet), $t$ (triplet), $q$ (quartet), $\mathrm{m}$ (multiplet), br (broad). The lists of coupling constants $(\mathrm{J})$ correspond to the order of multiplicity assignment and are reported in Hertz $(\mathrm{Hz})$. Whenever necessary, APT, HMQC and $\mathrm{HMBC}$ sequences (when necessary) were used for $13 \mathrm{C}$ spectra assignment. All melting points were uncorrected and were recorded in open capillary tubes using a Buchi melting point apparatus. High resolution mass spectra were obtained on QStar Elite (Applied Biosystems SCIEX).

The enediyne 4a $(250 \mathrm{mg})$ was prepared by using the procedure detailed in supporting information. white solid. m.p. $=100{ }^{\circ} \mathrm{C} .{ }^{1} \mathbf{H}$ NMR (400 $\left.\mathbf{M H z}, \mathbf{C D C l}_{3}\right) \boldsymbol{\delta}: 7.41(1 \mathrm{H}, \mathrm{dd}, J=6.5$ and $\left.1.5 \mathrm{~Hz}, \mathrm{CH}_{\mathrm{ar}}\right), 7.32-7.24\left(3 \mathrm{H}, \mathrm{m}, \mathrm{CH}_{\mathrm{ar}}\right), 4.52\left(1 \mathrm{H}, \mathrm{d}\right.$, A part of AB system, $\left.J=15.8 \mathrm{~Hz}, \mathrm{CH}_{2}\right)$, $4.49\left(2 \mathrm{H}, \mathrm{s}\right.$, superimposed $\left.\mathrm{CH}_{2}\right), 4.36\left(1 \mathrm{H}, \mathrm{d}, \mathrm{B}\right.$ parto f AB system, $\left.J=15.7 \mathrm{~Hz}, \mathrm{CH}_{2}\right), 2.75(1 \mathrm{H}$,

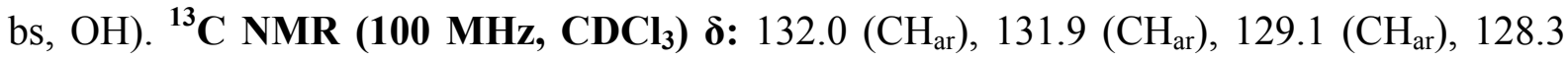
$\left(\mathrm{CH}_{\mathrm{ar}}\right), 126.1\left(\mathrm{C}_{\mathrm{ar}}\right), 124.0\left(\mathrm{C}_{\mathrm{ar}}\right), 92.6\left(\mathrm{C}_{\mathrm{C} \equiv \mathrm{C}}\right), 87.9\left(\mathrm{C}_{\mathrm{C} \equiv \mathrm{C}}\right), 83.5\left(\mathrm{C}_{\mathrm{C} \equiv \mathrm{C}}\right), 80.6\left(\mathrm{C}_{\mathrm{C} \equiv \mathrm{C}}\right), 51.6\left(\mathrm{CH}_{2}\right)$, 
$46.3\left(\mathrm{CH}_{2}\right) .{ }^{19} \mathbf{F}$ NMR (376 MHz, $\left.\mathbf{C D C l}_{3}\right)$ 8: -137.9 (2F), -145.2 (1F), -158.2 (2F). HRMS (ESI): $\mathrm{m} / \mathrm{z}$ : calcd for $[\mathrm{M}+\mathrm{Na}]^{+} \mathrm{C}_{18} \mathrm{H}_{9} \mathrm{O}_{2} \mathrm{SF}_{5} \mathrm{Na}$ : 407.0135, found: 407.0136 .

The enediyne 4b (130 mg) was prepared by using the procedure detailed in supporting information. ${ }^{1} \mathbf{H}$ NMR (400 MHz, $\left.\mathbf{C D C l}_{3}\right)$ 反: $7.42\left(1 \mathrm{H}, \mathrm{d}, J=7.4 \mathrm{~Hz}, \mathrm{CH}_{\mathrm{ar}}\right), 7.36-7.24(3 \mathrm{H}, \mathrm{m}$,

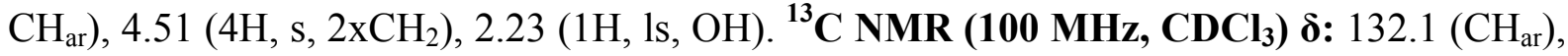
$132.0\left(\mathrm{CH}_{\mathrm{ar}}\right), 129.4\left(\mathrm{CH}_{\mathrm{ar}}\right), 128.2\left(\mathrm{CH}_{\mathrm{ar}}\right), 126.3\left(\mathrm{C}_{\mathrm{ar}}\right), 123.5\left(\mathrm{C}_{\mathrm{ar}}\right), 92.7\left(\mathrm{C}_{\mathrm{C} \equiv \mathrm{C}}\right), 88.3\left(\mathrm{C}_{\mathrm{C} \equiv \mathrm{C}}\right), 83.2$ $\left(\mathrm{C}_{\mathrm{C} \equiv \mathrm{C}}\right), 77.8\left(\mathrm{C}_{\mathrm{C} \equiv \mathrm{C}}\right), 51.6\left(\mathrm{CH}_{2}\right), 51.2\left(\mathrm{CH}_{2}\right) .{ }^{19} \mathbf{F}$ NMR (376 MHz, $\left.\mathbf{C D C l}_{3}\right) \boldsymbol{\delta}:-134.5(2 \mathrm{~F}),-$ $141.4(1 \mathrm{~F}),-157.4(2 \mathrm{~F})$. HRMS (ESI): $\mathrm{m} / \mathrm{z}$ : calcd for $\left[\mathrm{M}+\mathrm{NH}_{4}\right]^{+} \mathrm{C}_{18} \mathrm{H}_{13} \mathrm{NF}_{5} \mathrm{O}_{3} \mathrm{~S}: 418.0531$, found: 418.0526 .

The enediyne 4c $(350 \mathrm{mg})$ was prepared by using the procedure detailed in supporting information. ${ }^{1} \mathbf{H}$ NMR (400 MHz, $\left.\mathbf{C D C l}_{3}\right) \boldsymbol{\delta}: 7.36(1 \mathrm{H}, \mathrm{d}, J=7.8 \mathrm{~Hz}), 7.27-7.16(3 \mathrm{H}, \mathrm{m}), 4.56$ $(1 \mathrm{H}, \mathrm{d}, \mathrm{A}$ part of AB, $J=15.6 \mathrm{~Hz}), 4.50(1 \mathrm{H}, \mathrm{d}, \mathrm{B}$ part of AB, $J=15.6 \mathrm{~Hz}), 3.71(2 \mathrm{H}, \mathrm{t}, J=6.3$ $\mathrm{Hz}), 2.48(2 \mathrm{H}, \mathrm{t}, J=6.8 \mathrm{~Hz}), 1.82-1.65(5 \mathrm{H}, \mathrm{m}) .{ }^{13} \mathbf{C} \mathbf{N M R}\left(\mathbf{1 0 0} \mathbf{M H z}, \mathbf{C D C l}_{\mathbf{3}}\right) \boldsymbol{\delta}: 132.2\left(\mathrm{CH}_{\mathrm{ar}}\right)$, 132.1 $\left(\mathrm{CH}_{\mathrm{ar}}\right), 129.0\left(\mathrm{CH}_{\mathrm{ar}}\right), 127.5\left(\mathrm{CH}_{\mathrm{ar}}\right), 126.9\left(\mathrm{C}_{\mathrm{ar}}\right), 123.5\left(\mathrm{C}_{\mathrm{ar}}\right), 94.9\left(\mathrm{C}_{\mathrm{C} \equiv \mathrm{C}}\right), 88.2\left(\mathrm{C}_{\mathrm{C} \equiv \mathrm{C}}\right), 79.5$ $\left(\mathrm{C}_{\mathrm{C} \equiv \mathrm{C}}\right), 79.2\left(\mathrm{C}_{\mathrm{C} \equiv \mathrm{C}}\right), 62.5\left(\mathrm{CH}_{2}\right), 45.8\left(\mathrm{CH}_{2}\right), 31.9\left(\mathrm{CH}_{2}\right), 25.0\left(\mathrm{CH}_{2}\right), 19.4\left(\mathrm{CH}_{2}\right) .{ }^{19} \mathbf{F}$ NMR (400 MHz, $\left.\mathbf{C D C l}_{3}\right) \boldsymbol{\delta}$ : $-137.6(2 \mathrm{~F}),-145.5(1 \mathrm{~F}),-158.5(2 \mathrm{~F})$. HRMS (ESI): $m / z$ :calcd for $[\mathrm{M}+\mathrm{Na}]^{+} \mathrm{C}_{21} \mathrm{H}_{15} \mathrm{O}_{2} \mathrm{SF}_{5} \mathrm{Na}: 449.0605$, found: 449.0605 .

The enediyne 4d $(57 \mathrm{mg})$ was prepared by using the procedure detailed in supporting information. ${ }^{1} \mathbf{H}$ NMR (400 MHz, $\left.\mathbf{C D C l}_{3}\right)$ 8: $7.94\left(1 \mathrm{H}, \mathrm{s}, \mathrm{CH}_{\mathrm{ar}}\right), 7.86\left(1 \mathrm{H}, \mathrm{s}, \mathrm{CH}_{\mathrm{ar}}\right), 7.75(2 \mathrm{H}$, m, $\left.\mathrm{CH}_{\mathrm{ar}}\right), 7.51\left(2 \mathrm{H}, \mathrm{m}, \mathrm{CH}_{\mathrm{ar}}\right), 4.57\left(1 \mathrm{H}, \mathrm{A}\right.$ part of an $\mathrm{AB}$ system, $\left.\mathrm{d}, J=15.8 \mathrm{~Hz}, \mathrm{CH}_{2}\right), 4.54(2 \mathrm{H}$, $\left.\mathrm{s}, \mathrm{CH}_{2}\right), 4.39\left(1 \mathrm{H}, \mathrm{B}\right.$ part of an AB system, d, $\left.J=15.6 \mathrm{~Hz}, \mathrm{CH}_{2}\right), 2.81(1 \mathrm{H}, 1 \mathrm{~s}, \mathrm{OH}) .{ }^{13} \mathbf{C} \mathbf{~ N M R}$ $\left.(\mathbf{1 0 0} \mathbf{M H z}, \mathbf{C D C l})_{3}\right)$ d: $132.8\left(\mathrm{C}_{\mathrm{ar}}\right), 132.5\left(\mathrm{CH}_{\mathrm{ar}}\right), 132.2\left(\mathrm{C}_{\mathrm{ar}}\right), 132.1\left(\mathrm{CH}_{\mathrm{ar}}\right), 128.0\left(\mathrm{CH}_{\mathrm{ar}}\right), 127.8$ $\left(2 \mathrm{xCH}_{\mathrm{ar}}\right), 127.7\left(\mathrm{CH}_{\mathrm{ar}}\right), 121.9\left(\mathrm{C}_{\mathrm{ar}}\right), 120.5\left(\mathrm{C}_{\mathrm{ar}}\right), 91.9\left(\mathrm{C}_{\mathrm{C} \equiv \mathrm{C}}\right), 88.1\left(\mathrm{C}_{\mathrm{C} \equiv \mathrm{C}}\right), 83.6\left(\mathrm{C}_{\mathrm{C} \equiv \mathrm{C}}\right), 80.2$

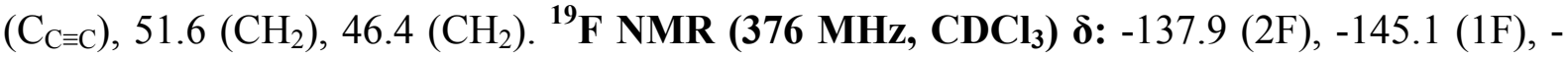
158.1 (2F). HRMS (ESI): $m / z$ : calcd for $[\mathrm{M}+\mathrm{H}]^{+} \mathrm{C}_{22} \mathrm{H}_{12} \mathrm{~F}_{5} \mathrm{O}_{2} \mathrm{~S}: 435.0473$, found: 435.0468 .

The compound 4e (288 $\mathrm{mg})$ was prepared by using the procedure detailed in supporting information. ${ }^{1} \mathbf{H}$ NMR (400 MHz, $\left.\mathbf{C D C l}_{3}\right) \boldsymbol{\delta}: \mathbf{7} .38-7,25\left(5 \mathrm{H}, \mathrm{m}, \mathrm{CH}_{\text {arom }}\right), 4,51$ (1H, d, A part of AB pattern, $\left.J=15.6 \mathrm{~Hz}, \mathrm{CH}_{2}\right) 4,36\left(1 \mathrm{H}, \mathrm{d}\right.$, B part of AB pattern, $\left.J=15.6 \mathrm{~Hz}, \mathrm{CH}_{2}\right) .{ }^{13} \mathbf{C ~ N M R}$ (100 MHz, $\left.\mathbf{C D C l}_{3}\right)$ \&: $133.3\left(\mathrm{CF}_{\mathrm{ar}}\right), 131.8\left(\mathrm{CH}_{\mathrm{ar}}\right), 129.7\left(\mathrm{CF}_{\mathrm{ar}}\right), 129.4\left(\mathrm{CH}_{\mathrm{ar}}\right), 128.7\left(\mathrm{CF}_{\mathrm{ar}}\right)$, $128.65\left(\mathrm{CH}_{\mathrm{ar}}\right) 125.2\left(\mathrm{C}-\mathrm{C}_{\mathrm{ar}}\right), 121.3(\mathrm{C}-\mathrm{S}(\mathrm{O})), 86.4\left(\mathrm{C}_{\mathrm{C} \equiv \mathrm{C}}\right), 76.0\left(\mathrm{C}_{\mathrm{C} \equiv \mathrm{C}}\right), 45.5\left(\mathrm{CH}_{2}\right) .{ }^{19} \mathbf{F} \mathbf{~ N M R}$ (400 MHz, $\left.\mathbf{C D C l}_{3}\right) \boldsymbol{\delta}$ : $-138.8(2 \mathrm{~F}),-146.8(1 \mathrm{~F})-159.8(2 \mathrm{~F})$. HRMS (ESI): $\mathrm{m} / z$ : calcd for $[\mathrm{M}+\mathrm{H}]^{+} \mathrm{C}_{15} \mathrm{H}_{7} \mathrm{~F}_{5} \mathrm{SO}: 331.0211$, found: 331.0209 .

The enediyne $4 \mathbf{f}(83 \mathrm{mg})$ was prepared by using the procedure detailed in supporting information. ${ }^{1} \mathbf{H}$ NMR (400 MHz, $\left.\mathbf{C D C l}_{3}\right) \delta$ : $7.99\left(1 \mathrm{H}, \mathrm{s}, \mathrm{CH}_{\mathrm{ar}}\right), 7.96\left(1 \mathrm{H}, \mathrm{d}, J=8.1 \mathrm{~Hz}, \mathrm{CH}_{\mathrm{ar}}\right)$, $7.48\left(1 \mathrm{H}, \mathrm{d}, J=8.1 \mathrm{~Hz}, \mathrm{CH}_{\mathrm{ar}}\right), 4.56-4.52\left(1 \mathrm{H}, \mathrm{d}, \mathrm{A}\right.$ part of AB system, $\left.J=16.0 \mathrm{~Hz}, \mathrm{CH}_{2}\right), 4.52$ $\left(2 \mathrm{H}\right.$, s, superimposed $\left.\mathrm{CH}_{2}\right), 4.40-4.35\left(2 \mathrm{H}, \mathrm{q}, J=7.1 \mathrm{~Hz}, \mathrm{CH}_{2}\right), 4.35-4.32(1 \mathrm{H}, \mathrm{d}, \mathrm{B}$ part of AB system, $\left.J=15.8 \mathrm{~Hz}, \mathrm{CH}_{2}\right), 2.91(1 \mathrm{H}, \mathrm{lt}, J=6.1 \mathrm{~Hz}, \mathrm{OH}), 1.39\left(3 \mathrm{H}, \mathrm{t}, J=7.1 \mathrm{~Hz}, \mathrm{CH}_{3}\right) .{ }^{13} \mathbf{C} \mathbf{~ N M R}$ $\left(\mathbf{1 0 0} \mathbf{M H z}, \mathbf{C D C l}_{3}\right) \delta$ : $165.2(\mathrm{C}=\mathrm{O}), 133.0\left(\mathrm{CH}_{\mathrm{ar}}\right), 131.9\left(\mathrm{CH}_{\mathrm{ar}}\right), 130.2\left(2 \mathrm{xC}_{\mathrm{ar}}\right), 129.9\left(\mathrm{CH}_{\mathrm{ar}}\right)$, $124.2\left(\mathrm{C}_{\mathrm{ar}}\right), 95.7\left(\mathrm{C}_{\mathrm{C} \equiv \mathrm{C}}\right), 87.0\left(\mathrm{C}_{\mathrm{C} \equiv \mathrm{C}}\right), 83.0\left(\mathrm{C}_{\mathrm{C} \equiv \mathrm{C}}\right), 81.5\left(\mathrm{C}_{\mathrm{C} \equiv \mathrm{C}}\right), 61.6\left(\mathrm{CH}_{2}\right), 51.6\left(\mathrm{CH}_{2}\right), 46.3$ $\left(\mathrm{CH}_{2}\right), 14.4\left(\mathrm{CH}_{3}\right) .{ }^{19} \mathbf{F}$ NMR (376 MHz, $\left.\mathbf{C D C l}_{3}\right)$ d: $-137.9(2 \mathrm{~F}),-144.8(1 \mathrm{~F}),-157.8(2 \mathrm{~F})$. HRMS (ESI): $m / z$ : calcd for $[\mathrm{M}+\mathrm{Na}]^{+} \mathrm{C}_{21} \mathrm{H}_{13} \mathrm{O}_{4} \mathrm{SF}_{5} \mathrm{Na}: 479.0347$, found: 479.0345 . 
The enediyne $4 \mathrm{~g}(278 \mathrm{mg})$ was prepared by using the procedure detailed in supporting information. ${ }^{1} \mathbf{H}$ NMR (400 MHz, $\left.\mathbf{C D C l}_{3}\right) \boldsymbol{\delta}:$ 7.45-7.44 (1H, m, $\left.\mathrm{CH}_{\mathrm{ar}}\right)$, 7.33-7.26 (3H, m, $\left.\mathrm{CH}_{\mathrm{ar}}\right)$, $4.55\left(1 \mathrm{H}, \mathrm{A}\right.$ part of an AB system, d, $\left.J=15.6 \mathrm{~Hz}, \mathrm{CH}_{2}\right), 4.44(1 \mathrm{H}, \mathrm{B}$ part of an AB system, d, $\left.J=15.6 \mathrm{~Hz}, \mathrm{CH}_{2}\right) .{ }^{13} \mathbf{C} \mathbf{N M R}\left(\mathbf{1 0 0} \mathbf{M H z}, \mathbf{C D C l}_{3}\right) \boldsymbol{\delta}: 132.6\left(\mathrm{CH}_{\mathrm{ar}}\right), 132.4\left(\mathrm{CH}_{\mathrm{ar}}\right), 129.2\left(\mathrm{CH}_{\mathrm{ar}}\right)$, $128.8\left(\mathrm{CH}_{\mathrm{ar}}\right), 124.9\left(\mathrm{C}_{\mathrm{ar}}\right), 124.0\left(\mathrm{C}_{\mathrm{ar}}\right), 87.5\left(\mathrm{C}_{\mathrm{C} \equiv \mathrm{C}}\right), 85.44\left(\mathrm{C}_{\mathrm{C} \equiv \mathrm{C}}\right), 85.41\left(\mathrm{C}_{\mathrm{C} \equiv \mathrm{C}}\right), 80.5\left(\mathrm{C}_{\mathrm{C} \equiv \mathrm{C}}\right), 45.8$

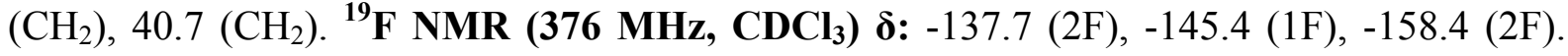
HRMS (ESI): $m / z$ : calcd for $[\mathrm{M}+\mathrm{H}]^{+} \mathrm{C}_{18} \mathrm{H}_{9} \mathrm{~N}_{3} \mathrm{OSF}_{5}: 410.0381$, found: 410.0383 .

The enediyne $5(115 \mathrm{mg})$ was prepared by using the procedure detailed in supporting information. ${ }^{1} \mathbf{H}$ NMR (400 MHz, $\left.\mathbf{C D C l}_{3}\right) \boldsymbol{\delta}:$ 7.77-7.74 (2H, m, $\left.\mathrm{CH}_{\mathrm{ar}}\right), 7.54-7.52\left(3 \mathrm{H}, \mathrm{m}, \mathrm{CH}_{\mathrm{ar}}\right)$, $7.43\left(1 \mathrm{H}, \mathrm{d}, J=7.5 \mathrm{~Hz}, \mathrm{CH}_{\mathrm{ar}}\right), 7.34-7.21\left(3 \mathrm{H}, \mathrm{m}, \mathrm{CH}_{\mathrm{ar}}\right), 4.53\left(2 \mathrm{H}, \mathrm{s}, \mathrm{CH}_{2}\right), 4.21(1 \mathrm{H}, \mathrm{s}, \mathrm{OH})$, $3.97\left(1 \mathrm{H}, \mathrm{d}, \mathrm{A}\right.$ part of AB system, $\left.J=16.1 \mathrm{~Hz}, \mathrm{CH}_{2}\right), 3.80(1 \mathrm{H}, \mathrm{d}, \mathrm{B}$ part of AB system, $J=16.1$ $\left.\mathrm{Hz}, \mathrm{CH}_{2}\right)$. ${ }^{13} \mathbf{C}$ NMR (100 MHz, $\left.\mathbf{C D C l}_{3}\right)$ \&: $142.5\left(\mathrm{C}_{\mathrm{ar}}\right), 131.9\left(\mathrm{CH}_{\mathrm{ar}}\right), 131.6\left(\mathrm{CH}_{\mathrm{ar}}\right), 131.4$ $\left(\mathrm{CH}_{\mathrm{ar}}\right), 129.4\left(2 \mathrm{xCH}_{\mathrm{ar}}\right), 128.6\left(\mathrm{CH}_{\mathrm{ar}}\right), 127.9\left(\mathrm{CH}_{\mathrm{ar}}\right), 126.5\left(\mathrm{C}_{\mathrm{ar}}\right), 125.0\left(\mathrm{C}_{\mathrm{ar}}\right), 124.5\left(2 \mathrm{xCH}_{\mathrm{ar}}\right)$, $93.3\left(\mathrm{C}_{\mathrm{C} \equiv \mathrm{C}}\right), 87.0\left(\mathrm{C}_{\mathrm{C} \equiv \mathrm{C}}\right), 83.6\left(\mathrm{C}_{\mathrm{C} \equiv \mathrm{C}}\right), 82.2\left(\mathrm{C}_{\mathrm{C} \equiv \mathrm{C}}\right), 51.5\left(\mathrm{CH}_{2}\right), 49.4\left(\mathrm{CH}_{2}\right)$. HRMS (ESI): $\mathrm{m} / z$ : calcd for $[\mathrm{M}+\mathrm{Na}]^{+} \mathrm{C}_{18} \mathrm{H}_{14} \mathrm{O}_{2} \mathrm{SNa}: 317.0607$, found: 317.0608 .

The enediyne $4 \mathbf{h}(285 \mathrm{mg})$ was prepared by using the procedure detailed in supporting information. ${ }^{1} \mathbf{H}$ NMR (400 MHz, $\left.\mathbf{C D C l}_{3}\right) \boldsymbol{\delta}: 8.46\left(1 \mathrm{H}, \mathrm{dd}, J=4.8\right.$ and $\left.1.5 \mathrm{~Hz}, \mathrm{CH}_{\mathrm{ar}}\right), 7.52(1 \mathrm{H}$, $\mathrm{dd}, J=7.9$ and $\left.1.6 \mathrm{~Hz}, \mathrm{CH}_{\mathrm{ar}}\right), 7.13\left(1 \mathrm{H}, \mathrm{dd}, J=7.9\right.$ and $\left.4.9 \mathrm{~Hz}, \mathrm{CH}_{\mathrm{ar}}\right), 4.89(1 \mathrm{H}, \mathrm{s}, \mathrm{CH}), 4.52-4.36$ $\left(4 \mathrm{H}, \mathrm{m}, \mathrm{CH}_{2}\right), 3.82-3.76\left(1 \mathrm{H}, \mathrm{m}, \mathrm{CH}_{2}\right), 3.52-3.49\left(1 \mathrm{H}, \mathrm{m}, \mathrm{CH}_{2}\right), 1.79-1.50\left(6 \mathrm{H}, \mathrm{m}, \mathrm{CH}_{2}\right) .{ }^{13} \mathrm{C}$ NMR (100 MHz, CDCl $\left.)_{3}\right)$ : $149.7\left(\mathrm{CH}_{\mathrm{ar}}\right), 144.9\left(\mathrm{C}_{\mathrm{ar}}\right), 139.3\left(\mathrm{CH}_{\mathrm{ar}}\right), 122.4\left(\mathrm{CH}_{\mathrm{ar}}\right), 121.1\left(\mathrm{C}_{\mathrm{ar}}\right)$, $96.6(\mathrm{CH}), 90.1\left(\mathrm{C}_{\mathrm{C} \equiv \mathrm{C}}\right), 85.4\left(\mathrm{C}_{\mathrm{C} \equiv \mathrm{C}}\right), 83.6\left(\mathrm{C}_{\mathrm{C}=\mathrm{C}}\right), 82.9\left(\mathrm{C}_{\mathrm{C} \equiv \mathrm{C}}\right), 61.9\left(\mathrm{CH}_{2}\right), 54.3\left(\mathrm{CH}_{2}\right), 45.7$

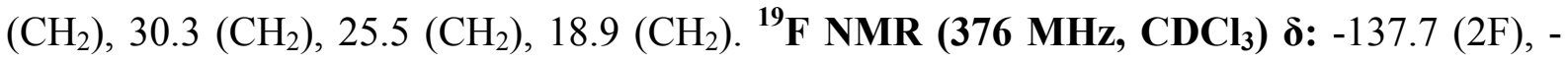
$145.0(1 \mathrm{~F}),-158.2$ (2F). HRMS (ESI): $\mathrm{m} / \mathrm{z}$ : calcd for $[\mathrm{M}+\mathrm{H}]^{+} \mathrm{C}_{22} \mathrm{H}_{17} \mathrm{~F}_{5} \mathrm{NO}_{3} \mathrm{~S}: 470.0844$, found: 470.0845 .

The enediyne 4i $(74 \mathrm{mg})$ was prepared by using the procedure detailed in supporting information. ${ }^{1} \mathbf{H}$ NMR (400 MHz, $\left.\mathbf{C D C l}_{3}\right) \boldsymbol{\delta}: 8.53\left(1 \mathrm{H}, \mathrm{dd}, J=5.0\right.$ and $\left.1.5 \mathrm{~Hz}, \mathrm{CH}_{\mathrm{ar}}\right), 7.65(1 \mathrm{H}$, dd, $J=7.9$ and $\left.1.5 \mathrm{~Hz}, \mathrm{CH}_{\mathrm{ar}}\right), 7.21\left(1 \mathrm{H}, \mathrm{dd}, J=7.9\right.$ and $\left.5 \mathrm{~Hz}, \mathrm{CH}_{\mathrm{ar}}\right), 4.54(1 \mathrm{H}$, A part of an AB system, d, $\left.J=16.1 \mathrm{~Hz}, \mathrm{CH}_{2}\right), 4.52\left(2 \mathrm{H}\right.$, s, superimposed $\left.\mathrm{CH}_{2}\right), 4.34(1 \mathrm{H}, \mathrm{B}$ part of an AB system,

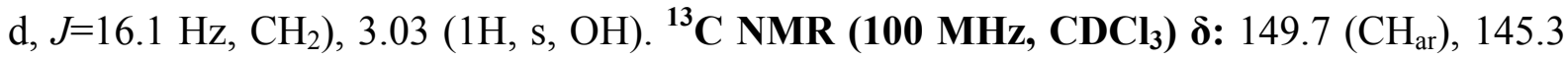
$\left(\mathrm{C}_{\mathrm{ar}}\right), 139.1\left(\mathrm{CH}_{\mathrm{ar}}\right), 122.3\left(\mathrm{CH}_{\mathrm{ar}}\right), 121.1\left(\mathrm{C}_{\mathrm{ar}}\right), 92.9\left(\mathrm{C}_{\mathrm{C} \equiv \mathrm{C}}\right), 85.5\left(\mathrm{C}_{\mathrm{C} \equiv \mathrm{C}}\right), 83.6\left(\mathrm{C}_{\mathrm{C} \equiv \mathrm{C}}\right), 83.2\left(\mathrm{C}_{\mathrm{C} \equiv \mathrm{C}}\right)$, $51.4\left(\mathrm{CH}_{2}\right), 46.3\left(\mathrm{CH}_{2}\right) .{ }^{19} \mathbf{F}$ NMR $\left(376 \mathrm{MHz}, \mathrm{CDCl}_{3}\right) \delta:-138.0(2 \mathrm{~F}),-144.7(1 \mathrm{~F}),-157.8(2 \mathrm{~F})$. HRMS (ESI): $m / z$ : calcd for $[\mathrm{M}+\mathrm{H}]^{+} \mathrm{C}_{17} \mathrm{H}_{9} \mathrm{~F}_{5} \mathrm{NO}_{2} \mathrm{~S}: 386.0269$, found: 386.0265 .

The enediyne $4 \mathbf{j}(97 \mathrm{mg})$ was prepared by using the procedure detailed in supporting information. ${ }^{1} \mathbf{H}$ NMR (400 MHz, $\left.\mathbf{C D C l}_{3}\right) \boldsymbol{\delta}: 8.52\left(1 \mathrm{H}, \mathrm{dd}, J=4.9\right.$ and $\left.1.6 \mathrm{~Hz}, \mathrm{CH}_{\mathrm{ar}}\right), 7.59(1 \mathrm{H}$, $\mathrm{dd}, J=7.9$ and $\left.1.6 \mathrm{~Hz}, \mathrm{CH}_{\mathrm{ar}}\right), 7.20\left(1 \mathrm{H}, \mathrm{dd}, J=7.9\right.$ and $\left.4.9 \mathrm{~Hz}, \mathrm{CH}_{\mathrm{ar}}\right), 4.88(2 \mathrm{H}, \mathrm{d}, J=1.5 \mathrm{~Hz}, \mathrm{CH})$, $4.56\left(1 \mathrm{H}\right.$, A part of AB pattern, $\left.\mathrm{d}, J=15.8 \mathrm{~Hz}, \mathrm{CH}_{2}\right), 4.50\left(2 \mathrm{H}, \mathrm{s}, \mathrm{CH}_{2}\right), 4.47(1 \mathrm{H}, \mathrm{B}$ part of AB pattern, d, $\left.J=15.8 \mathrm{~Hz}, \mathrm{CH}_{2}\right), 3.75\left(2 \mathrm{H}, \mathrm{m}, \mathrm{CH}_{2}\right), 3.58\left(2 \mathrm{H}, \mathrm{m}, \mathrm{CH}_{2}\right), 3.39\left(3 \mathrm{H}, \mathrm{s}, \mathrm{CH}_{3}\right) .{ }^{13} \mathbf{C}$ NMR (100 MHz, $\left.\mathbf{C D C l}_{3}\right)$ o: $149.8\left(\mathrm{CH}_{\mathrm{ar}}\right), 144.8\left(\mathrm{C}_{\mathrm{ar}}\right), 139.4\left(\mathrm{CH}_{\mathrm{ar}}\right), 122.5\left(\mathrm{C}_{\mathrm{ar}}\right), 121.1\left(\mathrm{CH}_{\mathrm{ar}}\right)$, $93.8\left(\mathrm{CH}_{2}\right), 89.5\left(\mathrm{C}_{\mathrm{C} \equiv \mathrm{C}}\right), 85.3\left(\mathrm{C}_{\mathrm{C} \equiv \mathrm{C}}\right), 83.9\left(\mathrm{C}_{\mathrm{C} \equiv \mathrm{C}}\right), 83.1\left(\mathrm{C}_{\mathrm{C} \equiv \mathrm{C}}\right), 71.8\left(\mathrm{CH}_{2}\right), 67.4\left(\mathrm{CH}_{2}\right), 59.1$ $\left(\mathrm{CH}_{3}\right), 54.6\left(\mathrm{CH}_{2}\right), 45.7\left(\mathrm{CH}_{2}\right) .{ }^{19} \mathbf{F}$ NMR (376 MHz, $\left.\mathbf{C D C l}_{3}\right)$ d: -137.8 (2F), -145.0 (1F), 158.2 (2F). HRMS (ESI): $m / z$ : calcd for $[\mathrm{M}+\mathrm{H}]^{+} \mathrm{C}_{21} \mathrm{H}_{17} \mathrm{NO}_{4} \mathrm{SF}_{5}: 474.0793$, found: 474.0792 . 


\section{Material and Methods}

\section{Cell culture}

Human cancer cell lines were obtained from American Type Culture Collection (ATCC). Cells were cultured in Dulbecco's modified Eagle's medium (DMEM, Gibco Life Technologies) supplemented with $10 \%$ heat-inactivated fetal calf serum (FCS, Lonza) at $37^{\circ} \mathrm{C}$ in a $100 \%$ humidified atmosphere containing $5 \% \mathrm{CO}_{2}$.

Cells were sub-cultured in new media every 3-4 days and were regularly checked for mycoplasma contamination and remained negative throughout the experiments.

\section{Cell viability assay}

Antiproliferative effect was measured using alamar blue. Briefly, cells were counted using the Cellometer Auto T4 apparatus (Nexcelom Bioscience LLC) automated cell counting technique and $0.2 \%$ trypan blue reagent (Aldrich). Cells (2000 cells/well) were seeded in 96 well-plates in the growth media overnight. Stock solutions of molecules were prepared in DMSO. Cells were exposed to increasing concentrations of compounds, in all case resulting in the presence of $0.1 \%$ (v:v) DMSO, control cells receiving only DMSO. Cells were then incubated for $70 \mathrm{~h}$, and the cell viability was assessed with CellTiter-Blue ${ }^{\circledR}$ Cell Viability Assay (Promega). 20 $\mu \mathrm{L}$ of resazurin stock solution was added to the treatment media per well. After $8 \mathrm{~h}$ incubation, the fluorescence was recorded at an excitation/emission wavelength of 560/590 nm, with a microplate reader (FLUOstar OPTIMA, BMG Labtech). The fluorescence measurement was normalized using culture medium without cells. Values measured were adjusted to negative growth control value (exposure to $0.1 \%$ DMSO alone for $100 \%$ cell growth). Data are expressed as the means \pm standard deviation (SD) of three independent experiments, each with triplicate measurements. Data were analyzed with Origin 6.0 software. The $\mathrm{IC}_{50}$ values of each compound were obtained from the dose-dependent curve fit.

\section{Cell proliferation assays upon photoactivation}

The cells were prepared with the same protocol as in the dark experiments. After $4 \mathrm{~h}$ incubation with the enediynes, light activation was achieved by irradiating the cells, at room temperature for 10 min using a transilluminator $\left(8 \mathrm{~W} 365 \mathrm{~nm}\right.$ tubes, $30 \%$ intensity ie $\approx 0,6 \mathrm{~J} / \mathrm{cm}^{2}$ energy, Biostep). As a control, the antiproliferative activity of the tested compounds was also assessed without UV light activation, the plate being protected with aluminium foil during UV irradiation. The intensity of UV light irradiation was determined with a UV radiometer (VLX$3 \mathrm{~W}$, Vilber Lourmat) with a $365 \mathrm{~nm}$ sensor. After irradiation, cells were incubated for $70 \mathrm{~h}$, and the cell viability was assessed with CellTiter-Blue ${ }^{\circledR}$. Data are expressed as the means \pm standard deviation (SD) of three independent experiments, each with triplicate measurements. Data were analyzed with Origin 6.0 software. The $\mathrm{IC}_{50}$ values of each compound were obtained from the dose-dependent curve fit.

\section{Plasmid DNA Photocleavage cleavage}


Compound 4 in DMSO (1 mM) was added to the solution of supercoiled PcDNA3 (5446 pb, $0.5 \mu \mathrm{g}$ ) in TE buffer (tris-HCl + EDTA, $20 \mu \mathrm{L}, \mathrm{pH}$ 8) to reach $100 \mu \mathrm{M}$ of 4 as a final concentration. Samples were placed at a distance of $20 \mathrm{~cm}$ from LED source (Shimamatzu LC$\mathrm{L} 5,365 \mathrm{~nm}$ ) and irradiated at $37^{\circ} \mathrm{C}$ during 1 hour. Crude mixtures were then subjected to gel electrophoresis $\left(0.8 \%\right.$ agarose containing SYBR ${ }^{\circledR}$ Safe DNA gel Stain) in TAE 0.5X for $1 \mathrm{~h}$ at $100 \mathrm{~V}$, then pictures were taken thanks to FluorChem-Q apparatus equipped with filter.

\section{Microtubules immunofluorescence}

Cells were seeded in 24-well plates at $10.000 \mathrm{cells} / \mathrm{cm}^{2}$ on glass coverslips. After $48 \mathrm{~h}$, compounds dissolved in DMSO were added. After pre-defined times, cells were fixed with 0.5 $\mathrm{mL} 4 \%$ PFA for $20 \mathrm{~min}$ at room temperature. After three washes with PBS, cells were saturated and permeabilized for $1 \mathrm{~h}$ at room temperature using PBS containing BSA at $2 \%$ and Triton $\mathrm{X} 100$ at $0.1 \%$. Primary antibody directed against beta-tubulin was then added (mouse antihuman beta tubulin, sc-398937 from Santa Cruz, diluted at 1:100 in PBS/BSA 2\% accordingly to manufacturer's instructions). After three washes with PBS, cells were treated with secondary antibody directed against mouse $\mathrm{IgG}$ (goat anti-mouse $\mathrm{IgG}$, coupled to Alexa488 Green fluorochrome from Invitrogen diluted at 1:200 in PBS/BSA 2\%. After $1 \mathrm{~h}$ incubation at room temperature, cells were washed three times with PBS and coverslips were mounted with vectashield liquid, cealed with nailpolish and observed by optical epifluorescence microscope (objective 40x, magnification factor x1.6, Leica DMRB, equipped with Leica DFC 450C camera).

\section{Acknowledgement}

Financial assistance from ANR JCJC MOCER2, Région PACA, Aix-Marseille University is acknowledged.

\section{Table of Content}

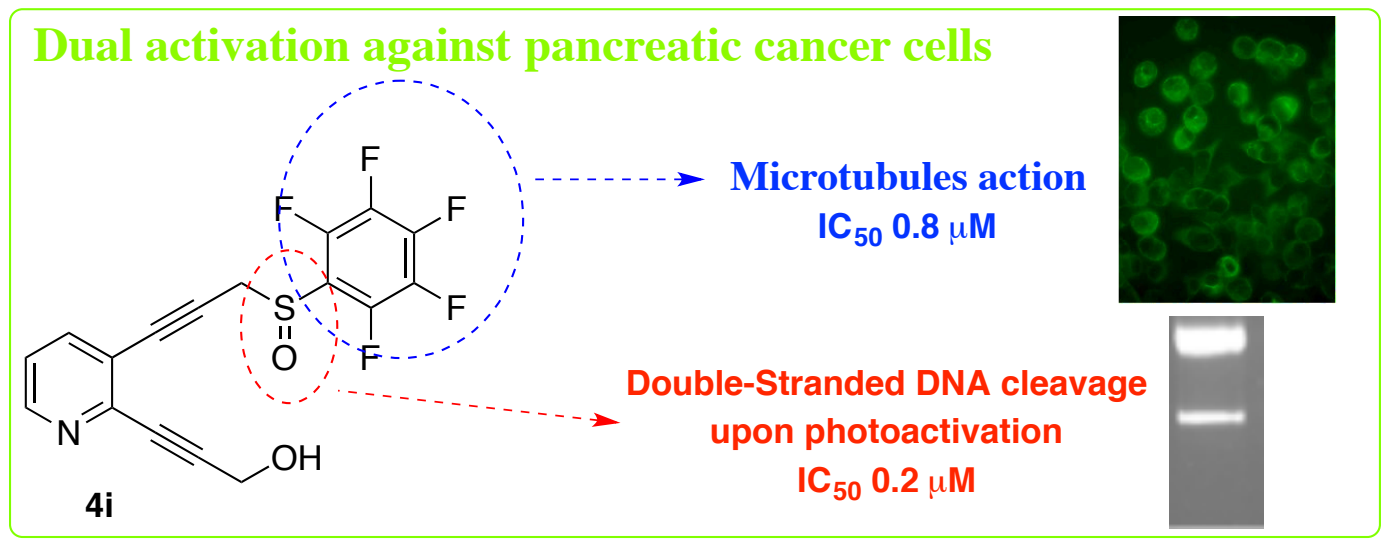

[1] For reviews see: (a) K.C. Nicolaou, A.L. Smith, E.W. Yue, Chemistry and biology of natural and designed enediynes, Proc. Natl. Acad. Sci. 90 (1993) 5881-5888; (b) M. Kar, A. Basak, Chem. Rev. 107 (2007) 2861-2890.

[2] R.-G. Shao, Curr. Mol. Pharmacol. 1 (2008) 50-60. 
[3] J.M.N. San Pedro, T.A. Beerman, M.M. Greenberg, Bioorg. Med. Chem. 20 (2012) 47444750 .

[4] J.-B. Chen, T.-R. Chern, T.-T. Wei, C.-C. Chen, J.-H. Lin, J.-M. Fang, J. Med. Chem. 56 (2013) 3645-3655.

[5] (a) M. Nechab, D. Campolo, J. Maury, P. Perfetti, N. Vanthuyne, D. Siri, M.P. Bertrand, J. Am. Chem. Soc. 132 (2010) 14742-14744; (b) M. Nechab, E. Besson, D. Campolo, P. Perfetti, N. Vanthuyne, E. Bloch, R. Denoyel, M.P. Bertrand, Chem. Commun. 47 (2011) 5286-5288; (c) D. Campolo, A. Gaudel-Siri, S. Mondal, D. Siri, E. Besson, N. Vanthuyne, M. Nechab, M.P. Bertrand, J. Org. Chem. 77 (2012) 2773-2783; (d) A. Gaudel-Siri, D. Campolo, S. Mondal, M. Nechab, D. Siri, M.P. Bertrand, J. Org. Chem. 79 (2014) 9086-9093; (e) D. Campolo, T. Arif, C. Borie, D. Mouysset, N. Vanthuyne, J.-V. Naubron, M.P. Bertrand, M. Nechab, Angew. Chem. Int. Ed. 53 (2014) 3227-3231.

[6] M.-J. Wu, C.-F. Lin, J.-S. Wu, H.-T. Chen, Tetrahedron Lett. 35 (1994) 1879-1882.

[7] (a) J. Wang, M. Sánchez-Roselló, J.L. Aceña, C. del Pozo, A.E. Sorochinsky, S. Fustero, V.A. Soloshonok, H. Liu, Chem. Rev. 114 (2014) 2432-2506; (b) J. Wang, M. SánchezRoselló, J.L. Aceña, C. del Pozo, A.E. Sorochinsky, S. Fustero, V.A. Soloshonok, H. Liu, Chem. Rev. 114 (2014) 2432-2506.

[8] S. Mondal, F. Dumur, B. Barbarat, O. Grauby, D. Gigmes, D. Olive, M.P. Bertrand, M. Nechab, Colloids Surf. B Biointerfaces. 112 (2013) 513-520.

[9] (a) D. Mitra, D.R. Banerjee, A.K. Das, A. Basak, Bioorg. Med. Chem. Lett. 20 (2010) 68316835; (b) W.-M. Dai, Chun Wo Chow, Ling Zhou, A. Ishii, Chi Wai Lau, Quan Li, W. Hamaguchi, S. Nishimoto, Bioorg. Med. Chem. Lett. 9 (1999) 2789-2794; (c) A. Basak, S. Das, D. Mallick, E.D. Jemmis, J. Am. Chem. Soc. 131 (2009) 15695-15704.

[10] Z. Wang, Y. Li, A. Ahmad, S. Banerjee, A.S. Azmi, D. Kong, F.H. Sarkar, Nat. Rev. Gastroenterol. Hepatol. 8 (2011) 27-33.

[11] M. Tsujie, S. Nakamori, S. Nakahira, Y. Takahashi, N. Hayashi, J. Okami, H Nagano, K. Dono, K. Umeshita, M. Sakon, M. Monden, Anticancer Res. 27 (2007) 2241-2249.

[12] M.J. Rathos, K. Joshi, H. Khanwalkar, S.M. Manohar, K.S. Joshi, J. Transl. Med. 10 (2012) 161.

[13] L.R. Jaidev, U.M. Krishnan, S. Sethuraman, Mater. Sci. Eng. C. 47 (2015) 40-47.

[14] (a) K.C. Nicolaou, G. Skokotas, P. Maligres, G. Zuccarello, E.J. Schweiger, K. Toshima, S. Wendeborn, Angew. Chem. Int. Ed. Engl. 28 (1989) 1272-1275; (b) K.C. Nicolaou, S. Wendeborn, P. Maligres, K. Isshiki, N. Zein, G. Ellestad, Angew. Chem. Int. Ed. Engl. 30 (1991) 418-420.

[15] (a) B. Shan, J.C. Medina, E. Santha, W.P. Frankmoelle, T.-C. Chou, R.M. Learned, M.R. Narbut, D. Stott, P. Wu, J.C. Jaen, T. Rosen, P.B.M.W.M. Timmermans, H. Beckmann, Proc. Natl. Acad. Sci. 96 (1999) 5686-5691; (b) P. Frankmoelle, J. C. Medina, B. Shan, M. R. Narbut, H. Beckmann, Drug Metabolism and Disposition, 28, (2000), 951- 958; (c) S.M. Rubenstein, V. Baichwal, H. Beckmann, D.L. Clark, W. Frankmoelle, D. Roche, E. Santha, S. Schwender, M. Thoolen, Q. Ye, J.C. Jaen, J. Med. Chem. 44 (2001) 3599-3605.

[16] J.D. Berlin, A. Venook, E. Bergsland, M. Rothenberg, A.C. Lockhart, L. Rosen, Clin. Colorectal Cancer. 7 (2008) 44-47.

[17] (a) S. Di Stefano, M. Mazzonna, E. Bodo, L. Mandolini, O. Lanzalunga, Org. Lett. 13, (2011), 142-145; (b) B.W. Vos, W.S. Jenks, J. Am. Chem. Soc. 24, (2002), 2544-2547. 
[18] D.J. Mayo, D.P. Turner, B.E. Zucconi, A.H. Predecki, Bioorg. Med. Chem. Lett. 17 (2007) 6116-6118.

[19] For selected examples see: (a) R.L. Funk, E.R.R. Young, R.M. Williams, M.F. Flanagan and T.L. Cecil, J. Am. Chem. Soc., 118, (1996) 3291-3292; (b) A. Evenzahav, N. J. Turro, J. Am. Chem. Soc. 120 (1998) 1835-1841; (c) P.J. Benites, R.C. Holmberg, D.S. Rawat, B. J. Kraft, L.J. Klein, D.G. Peters, H. H. Thorp and J. M. Zaleski, J. Am. Chem. Soc., 125 (2003) 6434; (d) M. Schmittel, G. Viola, F. Dall'Acqua, G. Morbach, Chem. Commun. (2003) 646647; (e) S.V. Kovalenko, I.V. Alabugin, Chem. Commun. (2005) 1444-1446.

[20] For a review see: B. Breiner, K. Kaya, S. Roy, W.-Y. Yang, I.V. Alabugin, Org. Biomol. Chem., 10 (2012) 3974-3987.

[21] (a) W.-Y. Yang, B. Breiner, S.V. Kovalenko, C. Ben, M. Singh, S. N. LeGrand, Q.-X.A. Sang, G.F. Strouse, J.A. Copland, I.V. Alabugin, J. Am. Chem. Soc., 131 (2009) 11458-11470; (b) Breiner, B.; Schlatterer, J. C.; Kovalenko, S. V.; Greenbaum, N. L.; Alabugin, I. V. Proc. Natl. Acad. Sci. U.S.A. 104 (2007) 13016. 